Article

\title{
Education for Sustainable Leadership: Fostering Women's Empowerment at the University Level
}

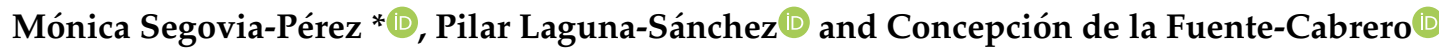 \\ Business Department. University Rey Juan Carlos, 28032 Madrid, Spain; pilar.laguna@urjc.es (P.L.-S.); \\ concepcion.delafuente@urjc.es (C.d.l.F.-C.) \\ * Correspondence: monica.segovia@urjc.es
}

Received: 2 September 2019; Accepted: 3 October 2019; Published: 9 October 2019

\begin{abstract}
Education is imperative to driving sustainability and gender equity. Moreover, it is extremely important to develop initiatives in sustainable leadership education for women in order for them to acquire skills and competencies in leadership and to improve their self-perception of their capabilities. The purpose of this study was to assess a Women's Leadership Program for university students. The sample consisted of 50 students enrolled in the program. A mixed-method approach was applied. Quantitative methods with a survey were conducted to evaluate the training and attainment of leadership skills. In the data analysis, a descriptive statistics variance analysis, using a Welch statistic and T2 Dunnett test, was applied. Qualitative research methods were conducted through three focus groups to evaluate changes in their perceptions of themselves and their self-confidence. The results suggest that the female students in the program obtained a level of leadership knowledge with practical tools for their future. The program inspired them and confirmed changes in their self-confidence and view of their personal capacities, including reflection on facing challenges in the work environment. The findings support the effectiveness of specific education in breaking two barriers, identified in the literature, for women in managerial positions: lack of training and self-confidence.
\end{abstract}

Keywords: education for sustainable leadership; gender equality; competencies; higher education; women managers

\section{Introduction}

Education is crucial for the achievement of sustainable development and is extraordinarily important for women's empowerment [1]. In 2015, the 2030 Agenda for Sustainable Development was adopted by the United Nations (UN) General Assembly and incorporated, as part of the 17 Sustainable Development Goals (SDGs), to "ensure inclusive and equitable quality education and promote lifelong learning opportunities for all" and to "achieve gender equality and empower all woman and girls" [2]. The European Commission fully integrated the SDGs in European policy, considering gender equality (SDG 5) to be one of the fundamental values of the European Union and promoting active policies to maximize female talent and achieve full participation and equal opportunities for leadership at all levels of political and economic decision-making for women [3,4].

In the Education for Sustainable Development Goals (ESDG): Learning Objectives, UNESCO aims to promote gender equality in education as one of the behavioral learning objectives (ESDG 4) and recommends that education for sustainable development should be included in all formal education curricula, including primary, secondary, and higher education [5].

In this context, the 2030 Agenda for Sustainable Development focuses on the need to acquire a set of key transversal competencies applicable to different contexts and purposes, along with professional careers [6]. The EU, since the implementation of the Bologna European Credit Transfer and Accumulation System, and Tunning project, has encouraged improvement in the acquisition of professional competences, 
changing learning approaches and outcomes, and emphasizing the importance of lifelong learning for professional and personal development in an unstable, global world. Most of the competences suggested by UNESCO [5] are related to the competences appropriate for a leader, such as critical thinking, collaboration, strategy, integrated problem-solving, anticipatory competency, normative competency, systems-thinking competency, and even self-awareness competency.

Understanding the relation between competences, skills, capacities, and types of leadership in relation to sustainability is a vital issue $[7,8]$, considering that sustainability is a complex problem for all agents in the system: organizations, managers, and persons involved $[9,10]$. Leadership is associated with creating engagement in teamwork, support, cooperation, empowerment, and membership. With regard to leadership capabilities [11], leadership theory has identified two orientations: task-oriented (strong-minded and power-seeking), which is more likely to apply to men, and interpersonally-oriented leadership or transformational leadership, which are linked to gender roles and associated with female managers. Nothouse [12] defined transformational leadership as team building, empathy, being more democratic and participative, and a greater emphasis on interpersonal skills. Sustainability and environmental concern, globalization, and the need for ethical organizational dynamics suggest that transformational leadership could be the best leadership style to drive sustainable outcomes for organizations [11]. The research pointed out that transformational leadership is associated with women [11]. Regarding this gender dimension, the type of leadership, capacities, and competencies in relation to sustainability were seen differently by women and men [7]. Previous research has shown that masculine values tend to be less oriented to environmental and social performance information, and with less socially-responsible investment [13]. In contrast, femininity is linked with "ethics of care"; pro-environmental attitudes; more socially conscious, altruistic behavior; and credibility [14-16]. Nevertheless, ecofeminism has shown that men's voices dominate in sustainable corporate and policy arenas connected to corporate responsibility, echoing organizational gendered norms [17]. Therefore, it is essential that women have managerial positions to drive a more sustainable organization. Education is one of the actions that can be developed to ensure that women's views are taken into consideration, through improving their opportunities to attain managerial positions.

In addition, sustainability and gender mainstreaming are considered to be basic instruments for policymakers to reduce inequalities. The literature has recognized that there can be no sustainability without gender equality [18-20], which has been a long-established priority for international and national organizations. Women's empowerment is essential for expanding economic growth, promoting social development, and achieving sustainable development. One of the main behavioral learning objectives is for females to be able to take measure of their surroundings in order to empower themselves or others who are discriminated against due to their gender [21,22]. Other stakeholders, such as civil organizations and movements (\#Metoo, Time's Up, YesAllWomen, massive marches on International Women's Day (IWD)), are seeking a more equitable society to improve world sustainability. The literature suggests that women leaders enable more sustainable development in corporations and are associated with greater control over corporate social responsibility [15]. In addition, from the point of view of the boards of directors, gender diversity [23] and increased numbers of women in upper-management positions permit businesses to shift from short-term profit maximization to a broader focus on longer-term goals. This also makes them more environmentally conscious, behave more ethically, have greater transparency, integrate the interests of multiple stakeholders, and pursue innovate initiatives [24-28].

Nevertheless, some differences persist in women's access to management positions in all economic sectors, as evidenced by the so-called "glass ceiling" [29-32]. According to the World Economic Forum (2018), women hold just 34\% of managerial positions and less than $7 \%$ in the four worst performing countries (Egypt, Saudi Arabia, Yemen, and Pakistan). Additionally, on average, globally, just $18 \%$ of ministers and $24 \%$ of parliamentarians are women. Data from the UN [2] show that women hold only $27 \%$ of management positions. Data for 2017 from the EU highlight the same tendency: women on boards of directors of the largest listed companies represent $24.6 \%$ of those with this position, and only $15.6 \%$ of all senior executives [4]. 
This situation contrasts with gender parity in education, where women have a greater presence in universities, and where they represent, in some degree courses, more than half of the students [33]. In addition, regarding the leadership capacity, there is no doubt that experience in leadership, solving problems, communication abilities, and self-confidence are essential for professional promotion.

Several studies conducted throughout the world have tried to identify the barriers that limit women's access to decision-making positions. Generic issues have been identified; for example, an insufficient female critical mass in managerial positions and discriminatory stereotypes, such as considering that effective leadership is associated with male attributes, structural and institutional obstacles, lifestyle choices, and incompatibility of the work-life balance. Human capital theories have explained these barriers to women accessing management positions as being due to a lack of specific training, stereotypes, and a lack of self-confidence [34-36]. Disadvantages in acquiring leadership competencies translate into limited opportunities in the labor market. Hence, education becomes fundamental in employment and subsequent professional development. Leadership education might be linked to occupational practice and consists of providing professionals with tools suited to resolving issues likely to arise in the course of practicing their respective managerial positions. At the same time, a specific program that focuses on a gendered perspective enables female students to furnish a suitable response to situations they will encounter in professional practice in the future.

On the other hand $[37,38]$, some suggest that gender stereotypes are what cause anchor biases about women's abilities as leaders. Stereotypes and social role theory [39] explain that men and women are allocated different roles in society due to their gender and these include different managerial discourses. The "think manager, think male" phenomenon [16] associates leadership with masculine characteristics and impedes women's career progression [40,41]. Women are expected to behave like women, but traditional female behavior conflicts with the desirable abilities of a leader [42]. For example, communication is considered a central leadership competency [43-46]. Social norms and stereotypes shape feminine communication as more indirect and emotional, whereas masculine communication is more direct and instrumental. The female style of communication is not considered suitable for leadership, as women's linguistic style is perceived as uncertain, nervous, and showing a lack of authority [43].

Gender roles affect individuals' perceptions of their own abilities, self-esteem, career ambitions, and self-imposed barriers [47]. Related to gender stereotypes, leadership is associated with male qualities as managers, including self-confidence, assertiveness, competitiveness, ambition, and emotional stability [48], while women are perceived as less competent. This external perception affects female self-abilities, confidence, and self-perception. Guillén, Mayo, and Karelaia [49] highlighted that self-confidence and ambition are based on the perceptions of others and the extent to which a woman sees herself as capable of leader performance external standards. Therefore, the environment and society's roles predict the extent to which men and women are seen as capable and promotable in their organizations. This lack of self-confidence and institutional confidence in them could explain why women do not put themselves forward for management positions.

In conclusion, female stereotypes, along with a lack of self-confidence in applying for leadership positions and a non-existence of specific training on leadership [35,36,50], require concrete actions within public administration, places of employment, academic institutions, and with women themselves [51]. Actions supported in education could create females' own social capital, result in promotion, and help them communicate their value for the organization.

In this context and in response to fostering women's self-confidence to develop leadership competences, a specific training program for female students was launched at the University Rey Juan Carlos in collaboration with the Women's CEO Association (WCA). The objective was to ensure the acquisition of skills, competencies, and tools for leadership, and to increase their self-perceptions, networking, and motivations.

The main objective of this paper is to show the results of this case study, analyzing its impact on female students. The paper is structured as follows: Section 2 describes the research background, 
design, methods, and sample; Section 3 outlines the main research findings; and Section 4 presents the discussion and main conclusions.

\section{Materials and Methods}

\subsection{The Research Background}

This research focuses on the results of the Women Leadership Program (WLP), which took place over two years, 2017 and 2018. The course was designed for female students only, based on the lack of training in leadership skills highlighted by the literature. The main objective of the WLP was that the female students enrolled on the program acquired skills, competences, and tools related to management and leadership. As a second goal, the course attempted to improve student motivation, self-esteem, and self-perception to empower females about their own value. Furthermore, it explained the difficulties women face in the labor market and with balancing their personal life, with case studies offered through managers' practical experiences and advice on how to overcome barriers. The total number of applications for enrolment in the WLP was four times the number of places offered; therefore, a selection process was necessary. The final groups constituted a heterogeneous team in terms of their academic profiles, including students pursuing Business, Social Science, and Engineering degrees. It was intended that the program provided access to leadership training not only to students in Business, but also to those with more technical profiles, such as women in Architecture, Medicine, and Engineering. Therefore, in the second year, the WLP ensured that half of the students enrolled were from these technical degrees.

The WLP included theoretical classes (a total of 24 hours), a case study, several visits to companies, a visit to the European Parliament in Brussels, and a coaching system. In the 2018 edition, students were also given an individualized test on their own leadership style and competencies, thanks to the collaboration of a Coaching Human Resources Company, Psicotec.

Currently, a good leader must know how to communicate, work in a team, negotiate, coordinate, and motivate a team in an increasingly changing and globalized environment [52]. Therefore, the theoretical modules were designed according to these needs. The topics covered areas such as

- Personal branding;

- Communicating efficiently;

- Social media and networking;

- Public speaking;

- Negotiating efficiently;

- Leadership style and techniques;

- Business management.

All the modules included specific reflections on the situation of women in the work environment. The 21 lecturers, men and women, were experienced managers from different economic sectors, who were very committed.

\subsection{Methods and Sample}

Evaluation of the impact on the acquisition of student competencies was a fundamental aspect of the WLP. A multi-source program evaluation design based on the students' perception was used for the analysis.

The evaluation considered two points: (a) a performance assessment of the WLP itself and the training received, and $(b)$ the results in terms of the skills and confidence acquired by the students themselves. A mixed-method approach was applied.

\section{- Quantitative Survey}

For the assessment of the WLP itself and the training received, a quantitative survey was developed at the end of each theoretical module via a self-administered survey. The questionnaire included a 
ten-point Likert scale with nine questions about theoretical and practical subjects, the documentation, and the lecturers, in addition to their previous knowledge about the topics, how the module contributed to their future and capability, and a global evaluation.

The final survey sample was a total of 50 students, 25 from each year. No one declined to answer the questionnaire. Most of them added some positive comments at the end of the questionnaire. On average, they were 21.6 years old and were in the final year of their Bachelor's degree in Business, Social Sciences, Law, Engineering, and Architecture. Some of them were combining their university classes with mandatory business practices.

\section{- Qualitative Study}

Secondly, for the evaluation of the results in the acquisition of skills and self-confidence, a qualitative methodology was used. At the end of each year, focus groups were held with the students to evaluate their perception of the program, the lessons they learned from it, and the personal change they experienced. Three focus groups were conducted, with eight participants in each one. A total of 24 students participated in the qualitative study. The interview schedule comprised open questions. In addition, four individual informal interviews were carried out with a selected group of students. The main objective of this qualitative approach was to obtain a deep comprehension of the students' perceptions about whether the program favored individual changes in their behavior or the way they think about or perceive themselves. It was fundamental to evaluate the real impact on improving self-confidence in university students who stand on the threshold of the labor market.

\subsection{Analysis}

The analysis of the quantitative data was realized with a classical descriptive analysis, with an evaluation of the mean, standard deviation, percentages, etc., using the SPSS v.25 software. Additionally, stochastic treatment of the data was carried out. The stochastic analysis relating to the inter-group comparisons was conducted using an analysis of variance (ANOVA). To test homoscedasticity, we used a Levene test. The analysis of variance was carried out using a Welch statistic, due to the heteroscedasticity of the sample. This test uses a modified F-statistic to analyze significant effects and is commonly used to deal with heteroscedastic samples [53]. Moreover, to identify inter-group differences, we used a T2 Dunnett test.

The qualitative data were recorded with participants' consent and were later transcribed. The analysis was carried out as a conventional content analysis (inductive analysis), in order to capture relevant information [54]. The analysis identified two categories: Program category related to the course performance, and how the program changed capacities and self-confidence categories, considering changes at the individual and personal level.

\section{Results}

The results of the quantitative and qualitative research are presented below.

\subsection{Quantitative Data}

Regarding the evaluation of theoretical classes, the general opinion of all students was that the course had been extraordinary. As can be seen in Figure 1, on a scale of 1 to 10, the average overall rating was 8.47 in 2017 and 8.63 in 2018. The global opinion was excellent, improving from year to year, not only because of the content, but also because of the teachers, the organization, and the coordination itself. A more detailed assessment shows that for all the items analyzed (theoretical, practical, documentation, etc.) (Figure 1), satisfaction was outstanding and that it increased in the second year. Above all, students valued the practical part of each module the most. 


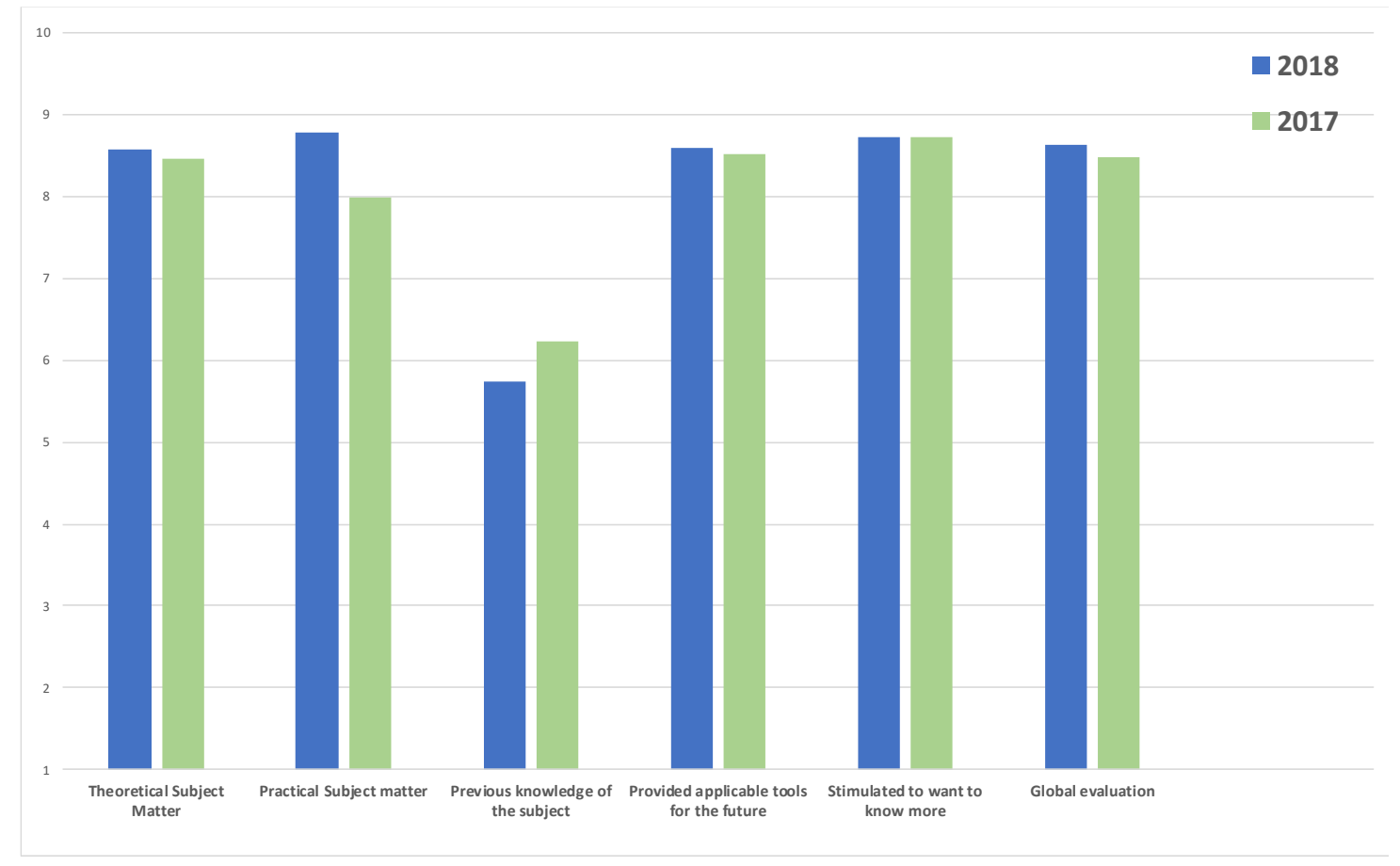

Figure 1. Detailed assessment comparison of 2017-2018 (on average).

The assessments related to how the program contributed to the participants' own capacities were especially interesting. As can be seen in Figure 1, their previous knowledge about the subjects was very low (6.2) and much lower in 2018 (5.73). Regarding the degree to which the topics provided them with applicable tools for the future, the evaluation was high, with values of 8.6 and 8.5, respectively, each year. In addition, the topics discussed instilled in them a desire to gain more depth of knowledge about the topic ( 8.7 for both years).

Regarding the evaluation of the specific program's subjects, all the subjects received excellent scores. Those with outstanding valuations are shown in Figure 2. Among them, Personal Branding, Social Media and Networking, and Communicate Efficiently are the topics with the best evaluation considering their theoretical and practical content, and the documentation received (Figure 2). However, there are differences from one year to the next, with better scores found in the second year (Figure 2).

One of the main concerns of the program's organizers was to know which, of all the topics, had a better evaluation in terms of content and, above all, which were considered to have contributed the most in terms of student skills development. For this reason, an ANOVA analysis was performed for the best rated subjects. Descriptive results of the subject evaluation by contents and skills provided are shown in Table 1. As shown, Personal Branding and Social Media and Networking were the ones that received the best results in relation to their theoretical content, with averages of 9.05 and 8.97, respectively. Regarding students' previous knowledge of the topic, Negotiating Efficiently and Personal Branding were the least known subjects. As regards the way the topic provided applicable tools for the future, Personal Branding and Public Speaking were the subjects that gave them the most skill capacities. Finally, Personal Branding and Social Media and Networking were the topics which most stimulated the desire to know more. 


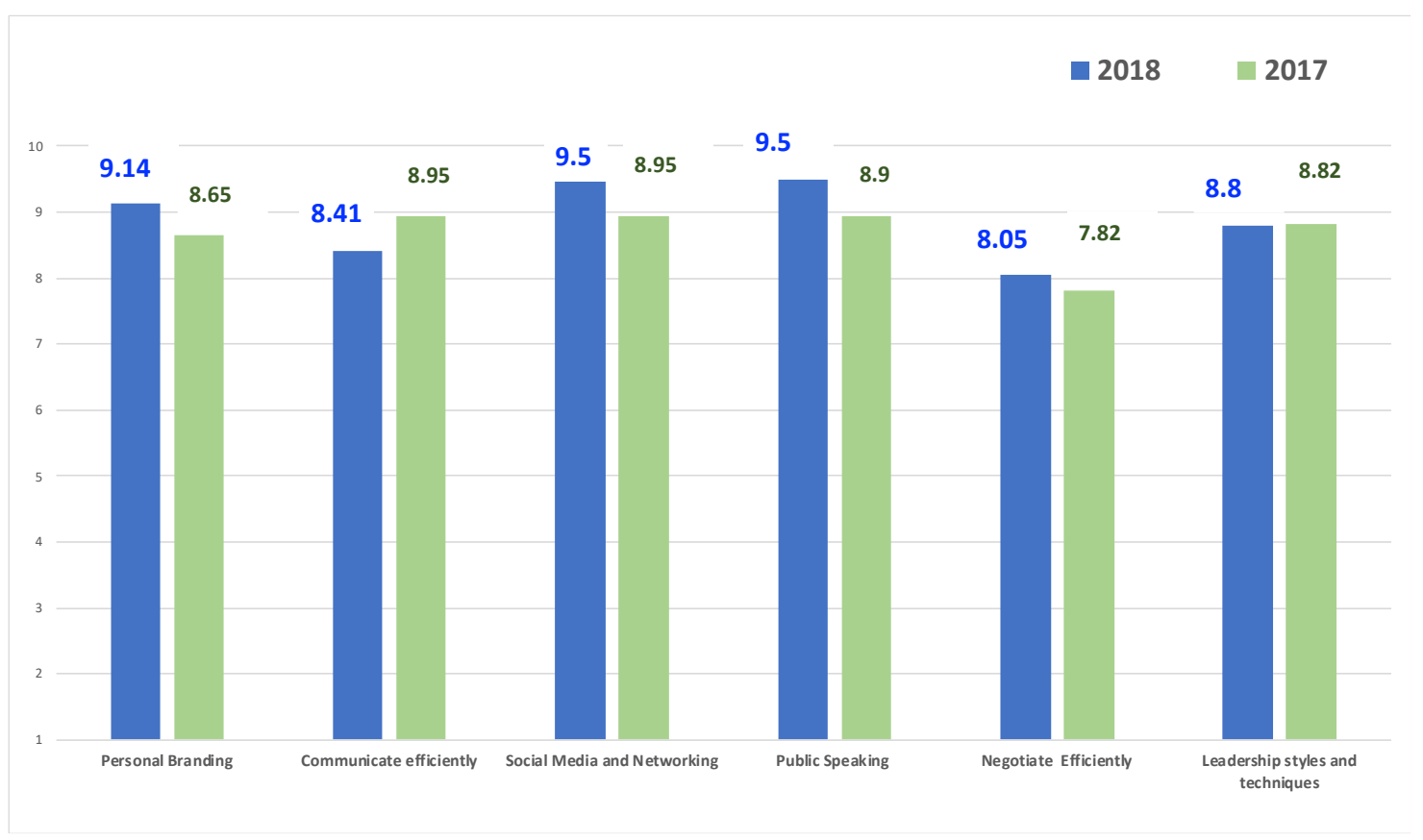

Figure 2. Subject comparative evaluation of 2017 and 2018 (on average).

Table 1. Descriptive results of the subject evaluation by contents and skills provided.

\begin{tabular}{cccc}
\hline Subject Evaluation & & Mean & Standard Deviation \\
\hline \multirow{2}{*}{ Theoretical Subject Matter } & Personal Branding & 9.05 & 1.068 \\
& Communicating Efficiently & 8.18 & 1.66 \\
& Social Media and Networking & 8.97 & 1.088 \\
Skills Provided & Public Speaking & 8.64 & 1.515 \\
& Negotiating Efficiently & 8 & 1.7 \\
\hline \multirow{2}{*}{ Previous knowledge of the subject } & & Mean & Standard Deviation \\
& Personal Branding & 5.79 & 1.567 \\
& Commial Media and Networking & 5.91 & 1.736 \\
& Public Speaking & 5.36 & 1.857 \\
Provided applicable tools for the future & Negotiating Efficiently & 5.84 & 1.903 \\
& Personal Branding & 9.07 & 1.993 \\
\hline & Commial Media and Networking & 8.92 & 1.009 \\
& Public Speaking & 9.03 & 1.626 \\
& Negotiating Efficiently & 8.22 & 1.085 \\
& Personal Branding & 9.21 & 1.464 \\
\hline \multirow{2}{*}{ Stimulated a desire to know more } & Social Media and Networking & 9.41 & 1.206 \\
& Public Speaking & 8.89 & 1.821 \\
& Negotiating Efficiently & 8.56 & 1.121 \\
& & 1.41 \\
& Comming & 1.382 \\
\hline
\end{tabular}

Nevertheless, descriptive analysis only provides an initial examination. To validate the robustness of these descriptive analyses, a stochastic analysis was realized. The analysis of variance permitted the identification of significant differences between subject evaluation and skills provided through all the specific subjects of the training program $(\mathrm{p}<0.05)$. Moreover, a post hoc test offered more in-depth information about the inter-group differences. Specifically, ANOVA analyses were applied, combining each factor with each variable. 
From these results, it was possible to conclude that only "Theoretical Subject Matter" and "Provide applicable tools for the future" had a significant influence on the evaluation of each subject, as the rest of the tests were rejected at a level of significance of less than five per cent (Table 2).

Table 2. Results of ANOVA analysis by group.

\begin{tabular}{lllcc}
\hline & Welch & G11 & G2 & Sig. \\
\hline $\begin{array}{c}\text { Theoretical Subject } \\
\text { Matter }\end{array}$ & 2.829 & 5 & 103.748 & 0.02 \\
$\begin{array}{c}\text { Provide applicable } \\
\text { tools for the future }\end{array}$ & 3.814 & 5 & 108.329 & 0.003 \\
\hline
\end{tabular}

After that, we conducted a post hoc analysis using a T2 Dunnett test for "Theoretical Subject Matter" and "Provide applicable tools for the future" through all the specific subjects of the training program to identify paired mean differences between groups (Table 3).

Table 3. T2-Tamhane results used to identify inter-group differences regarding economic activity.

\begin{tabular}{ccccc}
\hline Theoretical Subject Matter & Groups & Mean Differences & Standard Error & Sig \\
\hline Personal Branding & Communicating efficiently & $0.936 *$ & 0.301 & 0.004 \\
\hline $\begin{array}{c}\text { Provided applicable tools } \\
\text { for the future }\end{array}$ & Groups & Mean Differences & Standard Error & Sig \\
\hline Personal Branding & Communicating efficiently & $0.979 *$ & 0.289 & 0.017 \\
\hline \multicolumn{4}{c}{ * Statistically significant at 95\%. }
\end{tabular}

Results related to "Theoretical Subject Matter" only showed differences between the subjects Personal Branding and Communicating Efficiently (Table 3), with a lower evaluation of the second topic. Regarding which subject "provided an applicable tool for the future", significant differences were seen between the same topics. In conclusion, the subject "Personal Branding" was the topic that contributed the most tools for the future and had the highest theoretical performance (Table 3).

\subsection{Qualitative Results}

The qualitative analysis identified two main evaluation categories: one about course performance and one related to how the WLP changed the abilities and self-confidence of the students. Regarding the first, the results were coincident with the quantitative data. In this part of the study, only students' self-performance or confidence changes were analyzed.

In general, the program had a very significant effect on students. They considered that they had learned many tricks to communicate, lead, and apply skills for their working future. A good proof of this is that they would recommend it to other students. Specifically, they considered the following:

1. Meeting with people in the real business world had been a key part of the WLP. Participants valued the diversity of the speakers/professors and found them "very interactive, very exciting, very inspiring" (Focus group 1). In this sense, they valued the opportunity to meet great professionals; to analyze very important issues for them, which are not usually taught; and to realize the importance of certain issues for further professional development (Focus group 1). Students agreed that the course had been very useful for them, particularly as regards the specific reflections on the situation of women in the work environment and the challenges that they might face;

2. They agreed that they had more tools and guidelines when it comes to personal branding and public speaking, interacting with people, and communicating with more security. For example, they learned how to create more impact in the introduction and closing of professional presentations; 
3. They discovered what kind of leaders they were and, therefore, they determined the points that they needed to strengthen or improve upon when delegating, due to the individual tests they took;

4. The WLP helped them to know themselves better in relation to their professional field as they saw themselves in new situations which, if it were not for the course, they would not have faced;

5. The WLP helped them to manage their feelings of being overwhelmed.

The WLP organizers had a special interest in developing self-confidence, motivation, and ambition in students, teaching them practical advice, skills, and tools from real managers' experiences. In this regard, students recognized that the program offered them "a motivation to move forward every Wednesday" (Focus group 2). They were tired of hearing that "there is no future for them, that scholars and women find it difficult to grow in employment, etc." (Focus group 2). The course provided them with constant motivation, which many students needed to hear at this time in their lives. They all came out more empowered, and with a broader vision of the future by constantly being in contact with women who were a clear example of success and who gave them a shot of positivity: "Yes, you can!" (Focus group 2). Some students even commented that this motivation gave them the courage to demand certain labor rights in their current external practices or in their current jobs.

Furthermore, in capital letters, everyone thinks that it gave them a key to "Believe in themselves and self-confidence" (Focus group 3). There was a change in attitude towards their skills and aptitudes. In the interviews with the students and during the development of the program, many of them stated that they had gained motivation and self-confidence:

"It has served a lot on a personal level of self-esteem, motivation, trust, decision that you can get things done if you work with others". (Focus group 2).

"The program has provided tools to empower you as a woman, as a leader" (Focus group 3).

"Trust more in myself and in my qualities. I set a goal and know where I want to go and go on, go on, go on ..." (Focus group 1).

Additionally, this confidence began from the same selection process that they liked, not only because of what they learned during it (how a selection interview is carried out and surmounted), but also because it motivated them to know that they had been chosen from among a large number of applications.

Finally, the students also stated that the course had opened their eyes to the reality that they would have to face as women in the workplace, but also in their family balance:

"On a personal level it has helped a lot. It has opened my eyes to what is there. When I went to work ... now I have seen details that have made me alert. Nor do I have to be waiting and demonstrate, demonstrate, demonstrate. You, yourself know what you're worth, and you have to demand according to your merits according to what you're worth. I am more alert" (Focus group 1).

"The program wakes you up. I did not know that I will face problems between my family and my professional career..." (Focus group 3).

\section{Discussion and Conclusions}

The Sustainable Development Goals consider education to be a priority for sustainable development, driving inclusive and equitable opportunity for all. In this sense, education plays a critical role in assuring gender equality, particularly to help women attain managerial and leadership positions. The literature has highlighted women's lack of training in leadership abilities, skills, tools, and self-esteem [35,36], creating barriers for females to gain leadership positions. The present paper examines students' subjective outcome assessments of the "Women Leadership Program" carried out 
as a collaboration between The Rey Juan University (Spain) and The Women CEO Association of (WCA) over two consecutive years.

The quantitative study indicated that students had a strongly positive evaluation of the program. The female students involved expressed a great appreciation of all the subject areas, but especially those of Personal Branding, Social Media and Networking, and Communicating Efficiently. Most of the students expressed their previous ignorance about the subjects, especially in 2018. Furthermore, female learners indicated that they had reached a level of knowledge, and were given specific tools that allowed them to gain new capabilities in the topics learned. Therefore, this program might have broken one of the main barriers, highlighted by the literature, to reaching a managerial position: a lack of skills and training in leadership capacities such as communication, networking, negotiating, coordinating, being task-oriented, or building networks [34,44-46,55].

A second conclusion arises from the improved results obtained in the second year. The program's organizers placed a special emphasis on involving female students from Engineering and applied science degrees, as the literature has shown that this group has even worse possibilities of gaining managerial positions in ICT sectors and occupations [56]. The survey data from 2018, in which there were more students from engineering degrees, confirmed that there was a lower score for the item related to their previous knowledge of the subjects than in 2017. Associated with the acquisition of skills, the overall 2018 subject evaluation received higher scores than 2017, and the global program evaluation was a little more positive. Students seem to have had a better perception of the program's best use for real life. Based on these results, the program might have a strong influence on the improvement of female Engineering students' leadership skills, especially for those who are technically gifted, but who are too narrowly trained in the area of social, interpersonal, and managerial tools [57,58]. In fact, the Engineering students highlighted, as one of the strong outcomes of the program, that they most appreciated gaining practical orientation and interacting with a multidisciplinary group of teachers/lecturers and students who gave them a more real-life vision than regular university classes.

Analysis of the focus group discussions permitted the study of changes in personal capacities and self-confidence. The literature has shown that women have a poor personal perception of their leadership capacity, and low self-esteem and career ambition [59], which results in a self-imposed barrier, reducing women's ambition for promotion $[47,60]$. The qualitative results highlighted that the program had an extraordinary influence on female students. The participants confirmed not only an improvement in specific tools and skills, but also a positive change in their attitudes and their self-confidence; now, they believe in themselves. The program was inspiring for them and gave them the courage to demand certain labor rights. What is more, students highlighted that it was particularly useful for them to reflect on the situation of women in the work environment and the challenges that they might face. They confirmed that the program had opened their eyes to a reality that they had never thought about before.

Hence, the present study confirms a positive effect on two barriers that women face in attaining a managerial position shown by the literature: a lack of training and self-confidence. The results corroborate that leadership education $[61,62]$ has a positive effect and for female university students, could be a helpful action to improve their positions in organizations [63].

Nevertheless, the study has several limitations that open new research possibilities for the future. First, the present study is a case study that might be replicated considering other contexts. Second, methodologically speaking, it is possible that participants' responses could have been affected by social desirability; however, the qualitative results suggest that this effect was not so important. Participants, who were already working, explained, in focus groups, that they had identified and understood behavior in the work environment that they had not previously comprehended. Therefore, this could have a real impact. Follow-up testing is scheduled to evaluate the effect of the program after two years. Consequently, the findings could be validated by studying the situation of these students after their complete incorporation into the labor market. Third, as the present findings were based on a small sample, there is a need to replicate the study in the future with large samples 
using a longitudinal approach with program students in the next academic year. In addition, the study could be improved by applying autoethnography $[64,65]$. Fourth, as an improvement action for future WLP programs and the result's research, there could be an opportunity to extend this women-only leadership plan to male students and measure whether female empowerment occurs in a similar way as when they are alone. Furthermore, it could be appropriate to design a men-only program to raise awareness about the need for equality.

In conclusion, sustainability is a theme that extends to all realms of life, including education and gender equity. The present study stressed the relevance of education for women students to build their leadership strengths, skills, tools, and capabilities and also to reinforce their self-confidence. A strong commitment to developing leadership education for women could create a crucial scenario to break down the current barriers females face in obtaining management positions. Universities are well-placed to facilitate education that builds a more sustainable and gender-equitable legacy for future generations.

Author Contributions: Paper conceptualization, M.S.-P., P.L.-S. and C.d.1.F.-C.; study administration and data collection P.L.-S.; methodology, software and data validation, M.S.-P.; writing-original draft preparation: concepts on gender, methodology and results M.S.-P.; introduction and background: P.L.-S. and C.d.I.F.-C., discussion and conclusions: M.S.-P., P.L.-S. and C.d.1.F.-C.; review and editing: C.d.l.F.-C.

Funding: This research received no external funding.

Acknowledgments: The authors would like to express their gratitude to WCEO's support and to the students who participated in this study for their selflessness collaboration.

Conflicts of Interest: The authors declare no conflicts of interest.

\section{References}

1. Miotto, G.; López, M.-P.; Rodríguez, J.R. Gender equality and UN sustainable development goals: Priorities and correlations in the top business schools' communication and legitimation strategies. Sustainability 2019, 11, 302. [CrossRef]

2. The United Nations (UN). Transforming Our World: The 2030 Agenda for Sustainable Development; UN: New York, NY, USA, 2015. Available online: http://www.un.org/ga/search/view_doc.asp?symbol=A/RES/70/1\&Lang=E (accessed on 10 June 2019).

3. European Commission. Next Steps for a Sustainable European Future: European Action for Sustainability, COM (2016) 739. Available online: https://ec.europa.eu/europeaid/sites/devco/files/communication-nextsteps-sustainable-europe-20161122 (accessed on 16 August 2019).

4. European Union. Sustainable Development in the European Union. Monitoring Report on Progress towards the SDGS in an EU Context 2017. Available online: https://ec.europa.eu/eurostat/documents/3217494/8461633/ KS-04-17-780-EN-N.pdf (accessed on 16 August 2019).

5. United Nations Educational, Scientific and Cultural Organization (UNESCO). Education for Sustainable Development Goals: Learning Objectives; UNESCO: Paris, France, 2017. Available online: http://unesdoc.unesco. org/images/0024/002474/247444e.pdf (accessed on 16 May 2019).

6. Straková, Z.; Cimermanová, I. Critical thinking development-A necessary step in higher education transformation towards sustainability. Sustainability 2018, 10, 3366. [CrossRef]

7. Marshall, J. En-gendering Notions of Leadership for Sustainability. Gend. Work Organ. 2011, 18, 263-281. [CrossRef]

8. Rieckmann, M. Future-oriented higher education: Which key competencies should be fostered through university teaching and learning? Futures 2012, 44, 127-135. [CrossRef]

9. Metcalf, L.; Benn, S. Leadership for Sustainability: An Evolution of Leadership Ability. J. Bus. Ethics 2012, 112, 369-384. [CrossRef]

10. Haidar, N.H. Gender Leadership and Excellence: The Case of Higher Education in Lebanon. Adm. Sci. 2018, 8, 78. [CrossRef]

11. Alonso-Almeida, M.D.M.; Perramon, J.; Bagur-Femenias, L. Leadership styles and corporate social responsibility management: Analysis from a gender perspective. Bus. Ethics 2017, 26, 147-161. [CrossRef] 
12. Northouse, P.G. Introduction to Leadership: Concepts and Practice, 4th ed.; Sage Publications: Thousand Oaks, CA, USA, 2017; pp. 1-327.

13. Meriläinen, S.; Moisander, J.; Pesonen, S. The masculine mindset of environmental management and green marketing. Bus. Strateg. Environ. 2000, 9, 151-162. [CrossRef]

14. Gallén, M.L.; Peraita, C. The relationship between femininity and sustainability reporting. Corp. Soc. Resp. Env. Manag. 2017, 24, 496-508. [CrossRef]

15. Setó-Pamies, D. The relationship between women directors and corporate social responsibility. Corp. Soc. Resp. Env. Manag. 2015, 22, 334-345. [CrossRef]

16. Cook, A.; Glass, C. Women on corporate boards: Do they advance corporate social responsibility? Hum. Relat. 2018, 71, 897-924. [CrossRef]

17. Schein, V.E.; Mueller, R.; Lituchy, T.; Liu, J. Think manager-think male: A global phenomenon? J. Organ. Behav. 1996, 17, 33-41. [CrossRef]

18. Alarcón, D.M.; Cole, S. No sustainability for tourism without gender equality. J. Sustain. Tour. 2019, 27, 903-919. [CrossRef]

19. UN Women. Turning Promises into Action: Gender Equality in the 2030 Agenda for Sustainable Development. 2018. Available online: http://www.unwomen.org/-/media/headquarters/attachments/sections/library/ publications/2018/sdg-report-gender-equality-in-the-2030-agenda-for-sustainable-development-2018-en. pdf?la.en\&vs.4332 (accessed on 16 May 2019).

20. Bidegain, P.; Enriquez, C.R. Agenda 2030: A bold enough framework towards sustainable, gender just development? Gend. Dev. 2016, 24, 83-98. [CrossRef]

21. International Labour Organization. Strategy for Gender Mainstreaming in the Employment Sector 2010-15: Aligned with ILO Action Plan for Gender Equality 2010-15: Phase II: Programme and Budget 2012-13/International Labour Office, Employment Sector; ILO: Geneva, Switzerland, 2012.

22. The Organisation for Economic Co-operation and Development (OECD). Policy Coherence for Sustainable Development and Gender Equality Fostering an Integrated Policy Agenda; The Secretary-General of the OECD: Paris, France, 2018.

23. Rodríguez-Domínguez, L.; García-Sánchez, I.M.; Gallego-Álvarez, I. Explanatory factors of the relationship between gender diversity and corporate performance. Eur. J. Law. Econ. 2012, 33, 603-620. [CrossRef]

24. Han, S.; Cui, W.; Chen, J.; Fu, Y. Female CEOs and Corporate Innovation Behaviors-Research on the Regulating Effect of Gender Culture. Sustainability 2019, 11, 682. [CrossRef]

25. Hyun, E.; Yang, D.; Jung, H.; Hong, K. Women on boards and corporate social responsibility. Sustainability 2016, 8, 300. [CrossRef]

26. Fernandez-Feijoo, B.; Romero, S.; Ruiz-Blanco, S. Women on boards: Do they affect sustainability reporting? Corp. Soc. Resp. Env. Manag. 2014, 21, 351-364. [CrossRef]

27. Boulouta, I. Hidden connections: The link between board gender diversity and corporate social performance. J. Bus. Ethics 2013, 113, 185-197. [CrossRef]

28. Liao, L.; Luo, L.; Tang, Q. Gender diversity, board independence, environmental committee and greenhouse gas disclosure. Br. Account. Rev. 2015, 47, 409-424. [CrossRef]

29. Figueroa-Domecq, C.; Palomo, J.; Flecha-Barrio, M.D.; Segovia-Pérez, M. Double gender gap in tourism high-technology organisations: Results and corporate actions. In Information Communication Technology Tourism; Pesonen, J., Neidhardt, J., Eds.; Springer: Cham, Switzerland, 2019; pp. 383-395. [CrossRef]

30. Geys, B.; Sørensen, R.J. The impact of women above the political glass ceiling: Evidence from a Norwegian executive gender quota reform. Elect. Stud. 2019, 60, 1-10. [CrossRef]

31. González-Serrano, L.; Villacé-Molinero, T.; Talón-Ballestero, P.; Fuente-Cabrero, C.D.L. Women and the glass ceiling in the community of Madrid hotel industry. Int. J. Hum. Resour. Dev. Manag. 2018, 18, 91-111. [CrossRef]

32. Adams, R.B.; Funk, P. Beyond the glass ceiling: Does gender matter? Manag. Sci. 2012, 58, $219-235$. [CrossRef]

33. The Organisation for Economic Co-operation and Development (OECD). Education at a Glance 2018: OECD Indicators; OECD Publishing: Paris, France, 2018. [CrossRef]

34. Matheson, L.I.; Lyle, E. Gender bias in Canadian military leadership training. J. Ethnographic. Qual. Res. 2017, 12, 18-28.

35. Alkadry, M.G.; Tower, L.E. Unequal pay: The role of gender. Public Adm. Rev. 2006, 66, 888-898. [CrossRef] 
36. Baxter, J.; Wright, E.O. The glass ceiling hypothesis: A comparative study of the United States, Sweden and Australia. Gender. Soc. 2000, 14, 275-294. [CrossRef]

37. Heilman, M.E. Gender stereotypes and workplace bias. Res. Organ. Behav. 2012, 32, 113-135. [CrossRef]

38. Lyness, K.S.; Heilman, M.E. When fit is fundamental: Performance evaluation and promotions of upper-level female and male managers. J. Appl. Psychol. 2006, 91, 777-785. [CrossRef] [PubMed]

39. Eagly, A.H.; Gartzia, L.; Carli, L.L. Female advantage: Revisited. In The Oxford Handbook of Gender in Organizations; Kumra, S., Simpson, R., Burke, R.J., Eds.; Oxford University Press: New York, NY, USA, 2014; pp. 165-174. [CrossRef]

40. Rudman, L.A.; Moss-Rcusin, C.A.; Phelan, J.E.; Nauts, S. Status incongruity and backlash effects: Defending the gender hierarchy motivates prejudice against female leaders. J. Exp. Soc. Psychol. 2012, 48, 165-179. [CrossRef]

41. Koenig, A.M.; Eagly, A.H.; Mitchell, A.A.; Ristikari, T. Are leader stereotypes masculine? A meta-analysis of three research paradigms. Psychol. Bulletin. 2011, 137, 616-642. [CrossRef]

42. Zhao, J.; Jones, K. Women and Leadership in Higher Education in China: Discourse and the Discursive Construction of Identity. Adm. Sci. 2017, 7, 21. [CrossRef]

43. Von Hippel, C. Stereotype threat in the workplace. In Managing Diversity in Today's Workplace: Strategies for Employees and Employers; Paludi, M.A., Ed.; ABC-CLIO: Santa Barbara, CA, USA, 2012; pp. 47-71.

44. Castaño, C.; Laffarga, J.; Iglesias, C.; de Fuentes Martín, P.; Llorente, J.; Charlo, M.J.; Martínez, J.L. Mujeres y Poder Empresarial en España (Title in English: Women and Business Power in Spain). Instituto de la Mujer: Madrid, Spain, 2009.

45. Riggio, R.E. Leadership development: The current state and future expectations. Consult. Psychol. J. Practice. Res. 2008, 60, 383-392. [CrossRef]

46. Towler, A. Charismatic leadership development: Role of parental attachment style and parental psychological control. J. Leadersh. Org. Stud. 2005, 11, 15-25. [CrossRef]

47. Boone, J.; Veller, T.; Nikolaeva, K.; Keith, M.; Kefgen, K.; Houran, J. Rethinking a glass ceiling in the hospitality industry. Cornell. Hosp. Q. 2013, 54, 230-239. [CrossRef]

48. Kiser, A.I. Workplace and leadership perceptions between men and women. Gend. Manag. Int. J. 2015, 30, 598-612. [CrossRef]

49. Guillén, L.; Mayo, M.; Karelaia, N. The Competence-Confidence Gender Gap: Being Competent Is not (always) Enough for Women to Appear Confident. Available online: https://margaritamayo.com/wp-content/ uploads/2016/07/The-competence-confidence-gender-gap.pdf (accessed on 16 May 2019).

50. Segovia-Pérez, M.; Figueroa-Domecq, C. Mujer y Alta Dirección en el Sector Turístico; Síntesis: Madrid, Spain, 2014.

51. Johns, M.L. Breaking the glass ceiling: Structural, cultural, and organizational barriers preventing women from achieving senior and executive positions. Persp. Health. Inform. Manag. 2013, 10, 1-11.

52. Dunn, D.; Gerlach, J.M.; Hyle, A.E. Gender and leadership: Reflections of women in higher education administration. Int. J. Leadersh. Chang. 2014, 2. Available online: http://digitalcommons.wku.edu/ijlc/vol2/ iss1/2 (accessed on 18 August 2019).

53. Lee, S.; Lee, D.K. What is the proper way to apply the multiple comparison test? Korean J. Anesthesiol. 2018, 71, 353-360. [CrossRef] [PubMed]

54. Hsieh, H.F.; Shannon, S.E. Three approaches to qualitative content analysis. Qual. Health. Res. 2005, 15, 1277-1288. [CrossRef]

55. Alomair, M.O. Female leadership capacity and effectiveness: A critical analysis of the literature on higher education in Saudi Arabia. Int. J. High. Educ. 2015, 4, 81-93. [CrossRef]

56. Segovia-Pérez, M.; Castro-Núñez, R.B.; Santero-Sánchez, R.; Laguna-Sánchez, P. Being a woman in an ICT job: An analysis of the gender pay gap and discrimination in Spain. New Tech. Work Employ 2019, 1-10, in press. [CrossRef]

57. Farr, J.V.; Brazil, D.M. Leadership skills development for engineers. Eng. Manag. J. 2009, 21, 3-8. [CrossRef]

58. MacIntyre, P. Advancing leaders in engineering: Ways of learning leadership. Transform. Dialog. Teach. Learn. J. 2016, 8, 1-18.

59. Segovia-Pérez, M.; Figueroa-Domecq, C.; Fuentes-Moraleda, L.; Munoz-Mazon, A. Incorporating a gender approach in the hospitality industry: Female executives' perceptions. Int. J. Hosp. Manag. 2019, 76, 184-193. [CrossRef] 
60. Gino, F.; Wilmuth, C.A.; Brooks, A.W. Compared to men, women view professional advancement as equally attainable, but less desirable. Proc. Natl. Acad. Sci. USA 2015, 112, 12354-12359. [CrossRef] [PubMed]

61. Shek, D.T.; Sun, R.C. Promoting psychosocial competencies in university students: Evaluation based on a one-group pre-test/post-test design. Int. J. Disabil. Hum. Dev. 2012, 11, 229-234. [CrossRef]

62. Shek, D.T. Postlecture evaluation of a positive youth development subject for university students in Hong Kong. Sci. World J. 2012, 2012, 934679. [CrossRef]

63. Monkman, K. Framing gender, education and empowerment. Res. Compar. Int. Educ. 2011, 6, 1-13. [CrossRef]

64. Selzer, R.; Howton, A.; Wallace, F. Rethinking women's leadership development: Voices from the trenches. Adm. Sci. 2017, 7, 18. [CrossRef]

65. Vicary, A.; Jones, K. The implications of contractual terms of employment for women and leadership: An autoethnographic study in UK higher education. Adm. Sci. 2017, 7, 20. [CrossRef]

(C) 2019 by the authors. Licensee MDPI, Basel, Switzerland. This article is an open access article distributed under the terms and conditions of the Creative Commons Attribution (CC BY) license (http://creativecommons.org/licenses/by/4.0/). 